\title{
Training in digital competencies for health professionals: systematic mapping (2015-2019)
}

\author{
Antonia-María Fernández-Luque; María-Soledad Ramírez-Montoya; José-Antonio \\ Cordón-García
}

How to cite this article:

Fernández-Luque, Antonia-María; Ramírez-Montoya, María-Soledad; Cordón-García, José-Antonio (2021). "Training in digital competencies for health professionals: systematic mapping (2015-2019)". Profesional de la información, v. 30, n. 2, e300213.

https://doi.org/10.3145/epi.2021.mar.13

Manuscript received on $4^{\text {th }}$ January 2021 Accepted on $10^{\text {th }}$ March 2021

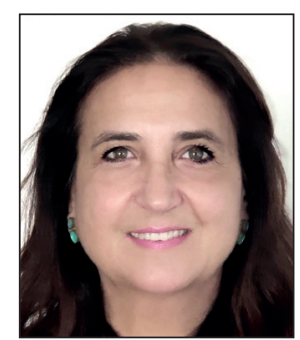

\section{Antonia-María Fernández-Luque https://orcid.org/0000-0002-4573-5591 \\ Universidad de Salamanca $\bowtie$ Group E-Lectra \\ Library Área de Gestión Sanitaria Este de Málaga-Axarquía \\ antoniam.fernandez.sspa@juntadeandalucia.es}

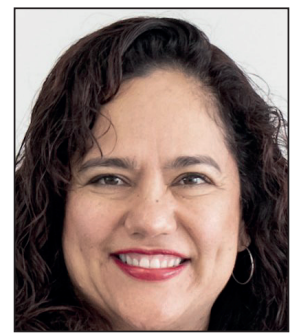

María-Soledad Ramírez-Montoya https://orcid.org/0000-0002-1274-706X

Tecnológico de Monterrey

Escuela de Humanidades y Educación

Avda. Garza Sada 20501 sur

Col. Tecnológico

64849 Monterrey (Nuevo León), México

solramirez@tec.mx

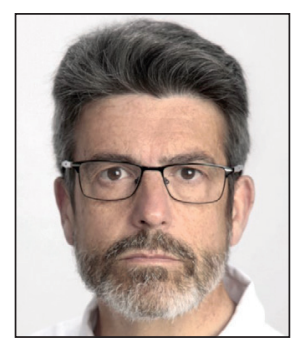

\author{
José-Antonio Cordón-García \\ https://orcid.org/0000-0002-8569-9417 \\ Universidad de Salamanca \\ Grupo E-Lectra \\ Facultad de Traducción y Documentación \\ Francisco de Vitoria, 6-16. \\ 37008 Salamanca, Spain \\ jcordon@usal.es
}

\begin{abstract}
Digital competencies are one of the main transversal competencies of the XXI century. By means of systematic mapping, international published papers and research on digital skills training were critically evaluated, generating a process that helps us to recognize information about health professionals and the type of educational technology used in training. With this in mind, we employed the systematic mapping method using the WoS and Scopus databases between 2015 and 2019 in English and Spanish, specifically focused on research articles. The five competencies of the European Framework of Digital Competence were used to analyze the articles, and the works were classified according to the educational technology used. Inclusion, exclusion, and quality criteria were applied. Two hundred and forty-eight articles were selected for the study. Most focused on the information literacy dimension (168) and used digital educational technology. In total, 27 papers were concerned with competence in communication, 19 with safety, and 12 with problem-solving. Only $8 \%$ of the papers were conducted in the context of health institutions, and $68 \%$ were based in an academic context. Articles related to the social field were found that dealt with aspects directly linked to health and safety. The publications on digital competencies used in the field of health mostly addressed the dimension of information competence, with a focus on the design and implementation of training activities in the management of information sources, instructional standards, curriculum design, and the competencies of the health librarian as an instructor.
\end{abstract}

\section{Keywords}

Digital competencies; Information literacy; Educational technology; Health librarians; Librarian roles; Digital literacy; Healthcare professionals; Educational Innovation; Higher education. 
Funding

This research has been supported by grants from the Andalusian public foundation Progreso y Salud, and Fundación Fimabis, Consejería de Salud de la Junta de Andalucía (Grant n. EF-0401-2019).

\section{Acknowledgments}

We are grateful to the Unesco/ICDE Chair "Movimiento de Educación Abierta de América Latina" and to the Tecnológico de Monterrey for the academic stay. We give special thanks to Abel García-González, Isolda-Margarita Castillo-Martínez, and Maday Coronel-Santos for methodological support and to Helena Martín-Rodero, librarian of the University of Salamanca, for the review of this article.

This research is carried out within the Doctoral Programme Education in the Knowledge Society of the Universidad de Salamanca. The authors would like to acknowledge the academic support of Writing Lab, TecLabs, Tecnológico de Monterrey, Mexico, in the production of this work.

\section{Introduction}

Digital competence (DC) is one of the key competencies that health professionals must possess as citizens to actively participate in society and lifelong learning. DC is defined as the critical and safe use of Information Society Technologies to generate the knowledge, attitudes, and skills needed to participate actively in digital environments (González-Fernández-ViIlavicencio, 2015). Within the 2030 Sustainable Development Goals, United Nations Educational, Scientific and Cultural Organization (Unesco) noted the importance of training in digital competence and published a comprehensive framework for assessing it (Laanpere, 2019). According to the Organization for Economic Co-operation and Development (OECD), e-skills training has enormous value, stimulating productivity and improving well-being, as it can empower people to decide what they want to learn, where and when they want to work, and how they get involved in society (OECD, 2019). The Library and Information Association (Cilip) emphasizes the relevance of this competence to all people, not just those in the educational field (Coonan, 2018). With regard to training in these competencies, the Association of College and Research Libraries (ACRL) published a document entitled Framework for Information Literacy for Higher Education, and subsequently, in 2013, it published a specific framework for nurses (Iannuzzi, 2000; ALA, 2013). Since the advent of the information literacy concept, new aspects related to other literacies have been added to the definition (Pinto; Cordón-García; GómezDíaz, 2010), which have been incorporated into the scientific production of concept in the health field (Pinto; Escalona-Fernández; Pulgarín, 2013). The reference frames emphasize the importance of using quality standards that guide training planning in social, academic, business, and health contexts. The training design in digital skills, which includes traditional information literacy, has changed over the years to adapt to changes in the information ecosystem.

The term information literacy (IL) has undergone a process of evolution and is interrelated with other literacies, such as computer and media literacy, resulting in the challenges of information and communication technologies (ICT) and of learning and knowledge technologies (LKT). Today, IL is integrated into digital skills that include multiple literacies. In 2018, Cilip in the United Kingdom synthesized the definition of IL as the ability to think critically, make balanced judgments about any type of information, and empower people to reach and express informed opinions and to fully engage with society (Sales, 2020). This definition is accepted as valid in the development of the European Digital Competence (DigCom) framework (Ferrari; Punie; Brečko, 2013). The European reference framework includes five competence areas, which are necessary to acquire the set of knowledge, skills, and attitudes that allow the use of information in digital media for the realization of tasks, problem solving, and content sharing and creation in a critical, ethical, and thoughtful manner autonomously for work, leisure, participation, and learning. DC also involves knowing how to securely manage digital identities and make creative and autonomous use of the devices and utilities available in the digital ecosystem. In this context, the involvement of information professionals is a key part of the design of training programs that target all educational levels for life.

When designing DC training, information professionals must be aware of the results of technology-mediated pedagogical research. Today, IL is conducted in a digital environment with active learning methods and innovative technologies. González-Pérez, Ramírez-Montoya, and García-Peñalvo (2019) classified innovative technologies into six categories: (1) digital pedagogies, which use technology to adapt to each area of knowledge, such as blended learning (b-learning) and multimedia technology; (2) technology models, which integrate innovation into collaborative learning environments; (3) adaptive technologies, which introduce new systems, such as e-learning and e-portfolios, and allow their use synchronously or asynchronously; (4) open technologies, which enable open access for the dissemination of knowledge, such as open platforms, repositories, MOOC courses, and open science (Hernández-Carranza; Romero-Corella; Ramírez-Montoya, 2015); (5) smart technologies, which use smart tools, including big data, data mining, and mobile learning (m-learning); and (6) technologies involving new processes that generate structural or functional changes, such as augmented reality, stimulation sensors, and virtual or remote laboratories. Some of the technologies described have been used in training developed in the library field.

Health librarians have traditionally trained their users on the tools and utilities available in library management information processing, but this training has not been, and should be, better integrated into health professionals' lifelong lear- 
ning (Muellenbach et al., 2018) as a cross-conversational competence. The training provided from the health library is aimed at different groups including students, health professionals, and citizens in general. It is focused on helping users become competent in the use and evaluation of information in the digital ecosystem. The World Health Organization proposed a global strategy on digital health in 2018 based on several eHealth reports that recognize the potential of digital technologies to advance sustainable development goals and support health systems in health promotion (WHO, 2016). Health professionals need to acquire the appropriate skills to work in the digital environment of healthcare practice, teaching, and research (Steen; Mao, 2016; Fernández-Luque, 2019; McGowan, 2019). Accordingly, information professionals have redesigned training strategies to meet new training demands and incorporated new pedagogical technologies (Ziegenfuss; LeMire, 2019; Ma; Stahl; Knotts, 2018).

Educational innovation provides support to incorporate technology to learn and teach digital skills. According to Ramírez-Montoya and Lugo-Ocando (2020), technologies make an important contribution to educational innovation. The development of information and communication technologies provides new possibilities for developing creative learning strategies (Pinto et al., 2019). Librarians are implementing new learning styles to meet current demands. It is important to find out which methods are the most effective and what the educational role of librarians dedicated to the formation of such skills should be.

Publications linking the concepts of DC and IL have led to theoretical and practical discussions that have contributed to instructional designs. Literature reviews have been performed to examine the evolution of concepts that have been incorporated into IL (Sample, 2020); the use of the flipped classroom technique (Strelan; Osborn; Palkmer, 2020), the importance of digital skills training for teachers (Intef, 2017), case studies for training with the participation of library professionals (Campal-García, 2019), and contributions to information library management processing (Valenzuela-González, 2016).

This work identifies the gap between theory and digital skills teaching practices and innovative pedagogical methods used for this purpose. It aims to map the characteristics of publications dealing with digital skills in health professionals from libraries that support healthcare professionals and/or health services as well as identify what technologies have been used in digital skills training for the purpose of identifying possibilities for training. The article presents the systematic method of literature mapping, followed by the results, analysis of findings, and conclusions.

\section{Methods}

The Systematic Mapping Study (SMS) enables the synthesis and scientific classification of a subject over a certain period of time to get an overview of the investigation (Cooper, 2016). This SMS was developed through a sequence that made it possible to understand the process of analyzing and classifying the information that we are considering. The processes recommended by Kroll et al. (2018) and García-González and Ramírez-Montoya (2019) were followed, including the definition of the objective and research questions, search delimitation, search definition, search and extraction of information, and creation of a classification scheme. The literature review protocol used by Kitchenham and Charters was selected, comprising the following stages (Kitchenham et al., 2010):

- Planning, which includes reflection on the need for review, question formulation, development of the review protocol, and evaluation of the review protocol.

- Driving, which includes the search, study selection, quality assurance, and data extraction.

- Results report, which includes the extraction and discussion of results, drafting according to the format chosen, and evaluation of results (Figure 1).

\subsection{Planning}

\subsubsection{Objective and research question}

The objective of this literature mapping is to identify the studies that have addressed training in digital skills aimed at health professionals, the educational technology used, the social-health context in which they were developed, and the results published from January 2015 to December 2019. Searches were performed in the Scopus and Web of Science (WoS) databases. The language filter was applied to retrieve English- and Spanish-language articles in the areas of librarianship and information science. MS-Excel software was used to administrate and manage the bibliographic records, and the progress was recorded based on the order of relevance to the following research questions: Table 1.

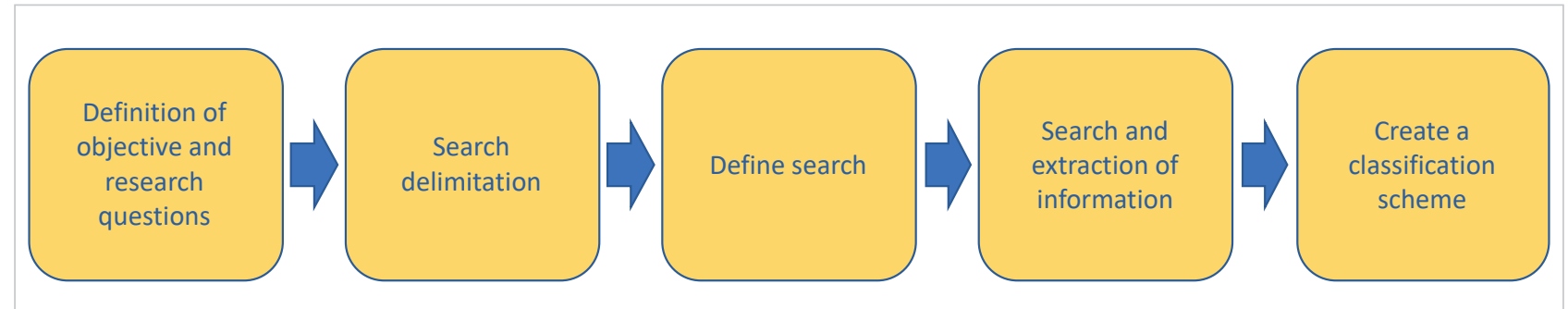

Figure 1. Systematic mapping study process 
Table 1. Research questions

\begin{tabular}{|c|c|}
\hline Question & Type of response \\
\hline $\begin{array}{l}\text { RQ1: How many studies are in the WoS and Scopus databases from } 2015 \\
\text { to 2019? }\end{array}$ & $\begin{array}{l}\text { Number of Scopus articles } \\
\text { Number of WoS articles } \\
\text { Number of duplicate items } \\
\text { Number of theoretical-conceptual articles } \\
\text { Number of empirical research articles }\end{array}$ \\
\hline RQ2: What are the most cited articles? & $\begin{array}{l}\text { Most cited authors } \\
\text { Most cited articles }\end{array}$ \\
\hline RQ3: What is the geographical distribution of the authors? & Authors' countries \\
\hline $\begin{array}{l}\text { RQ4: Which journals have the largest number of publications in this line } \\
\text { of research? }\end{array}$ & $\begin{array}{l}\text { Journals } \\
\text { Q1, Q2, Q3 or Q4, ESCI (Emerging Sources Citation Index). }\end{array}$ \\
\hline RQ5: In what contexts are the studies being conducted? & $\begin{array}{l}\text { Academic } \\
\text { Social } \\
\text { Business } \\
\text { Health }\end{array}$ \\
\hline $\begin{array}{l}\text { RQ6: What are the categories of digital competencies thar have been } \\
\text { studied? }\end{array}$ & $\begin{array}{l}\text { Information } \\
\text { Communication } \\
\text { Content creation } \\
\text { Security } \\
\text { Problem solving }\end{array}$ \\
\hline $\begin{array}{l}\text { RQ7 What are the emergency digital technologies that have resulted in } \\
\text { emergency issues in digital education? }\end{array}$ & $\begin{array}{l}\text { Technological models } \\
\text { Adaptive technologies } \\
\text { Open technologies } \\
\text { Smart technologies } \\
\text { Disruptive technologies }\end{array}$ \\
\hline
\end{tabular}

\subsubsection{Development of the review protocol}

To answer the research questions, inclusion and exclusion criteria were defined to exclude documents that were not relevant. The databases to be consulted were identified, and the search terms were defined. It is necessary to define criteria related to the time, document type, language, and relevance of the article topic. For this study, the following inclusion criteria were used: studies on training in digital competencies that corresponded to articles published in peer-reviewed journals in the WoS, Scopus, and ESCI databases; articles published from January 2015 to November 2019 in English and Spanish; and articles related to the area of information, documentation, and education. Validation was done with peer review to check the identification of the answers. In cases of discrepancies, agreements were reached for the selection of answers and to approach $100 \%$ data verification. Exclusion criteria included duplicate articles, systematic literature reviews, books, book chapters, and lectures (Table 2).

Table 2. Inclusion, exclusion, and quality criteria

\begin{tabular}{|l|l|l|}
\hline \multicolumn{1}{|c|}{ Including criteria } & \multicolumn{1}{|c|}{ Excluding criteria } & \multicolumn{1}{|c|}{ Quality criteria } \\
\hline $\begin{array}{l}\text { Studies on training in digital literacy in the } \\
\text { WoS and Scopus databases }\end{array}$ & $\begin{array}{l}\text { Studies that do not address information } \\
\text { literacy. }\end{array}$ & $\begin{array}{l}\text { Contribution of valuable information regar- } \\
\text { ding open innovation }\end{array}$ \\
\hline Research articles & Conference papers, book chapters & $\begin{array}{l}\text { Consistency between objective, method, } \\
\text { and results }\end{array}$ \\
\hline Articles published in high impact journals. & $\begin{array}{l}\text { Articles that have not been published in high } \\
\text { impact journals }\end{array}$ & \\
\hline Articles published between 2015-2019 & $\begin{array}{l}\text { Articles published outside the range 2015- } \\
2019\end{array}$ & \\
\hline Articles within the training field & Articles outside the training field & \\
\hline Articles peer-reviewed & $\begin{array}{l}\text { Duplicate articles. Articles not in English or } \\
\text { Spanish }\end{array}$ & \\
\hline
\end{tabular}

\subsection{Driving}

\subsubsection{Search strategies and resources}

Kroll et al. (2018), stress the importance of using synonyms in the search string for all databases being consulted. Following these recommendations, the search strategies that were applied in both databases were defined as shown in Table 3. 


\begin{tabular}{|c|c|}
\hline Scopus search strings & WoS search strings \\
\hline $\begin{array}{l}\text { (TITLE-ABS-KEY (("librarian*" OR "hospital librarian*" OR "health libra- } \\
\text { rian*" OR "nursing librarian")) AND TITLE-ABS-KEY ("health literacy" OR } \\
\text { " information literacy" OR "social literacy" OR "digital competence*" } \\
\text { OR "Information Literacy Competency" OR "Literac* Competenc*") } \\
\text { AND TITLE-ABS-KEY ("training program*" OR "Curricul* design*" OR } \\
\text { "instruct* design*" OR "elearning" OR "e-learning" OR "online" OR "dis- } \\
\text { tance learning" OR "blended learning" OR "blearning" OR "b-learning" } \\
\text { OR "MOOC" OR "online course")) AND DOCTYPE (ar) AND PUBYEAR > } \\
2014\end{array}$ & $\begin{array}{l}\text { TODOS LOS CAMPOS: ("Nursing" OR "HEALTH PROFESSIONAL" OR "me- } \\
\text { dical*" OR "librarian*" OR "hospital librarian*" OR "health librarian*" OR } \\
\text { "nursing librarian*") AND TODOS LOS CAMPOS: ("health literacy" OR" } \\
\text { information literacy" OR "social literacy" OR "digital competence*" OR } \\
\text { "Information Literacy Competency" OR "Literac* Competenc*") AND } \\
\text { TODOS LOS CAMPOS: ("training program*" OR "Curricul* design*" OR } \\
\text { "instruct* design*" OR "elearning" OR "e-learning" OR "online" OR "dis- } \\
\text { tance learning" OR "blended learning" OR "blearning" OR "b-learning" } \\
\text { OR "MOOC" OR "online course") Filtered by: TIPOS DE DOCUMENTOS: ( } \\
\text { ARTICLE ) AND IDIOMAS: ( ENGLISH OR SPANISH ) } \\
\text { Time frame: Last five years. Index: SCI-EXPANDED, SSCI, A\&HCI, CP- } \\
\text { CI-S, CPCI-SSH, BKCI-S, BKCI-SSH, ESCI, CCR-EXPANDED, IC. }\end{array}$ \\
\hline
\end{tabular}

\subsubsection{Extraction of the articles through database searches}

After implementing the inclusion and exclusion criteria and eliminating duplicates, letters, books, or systematic literature reviews (SRL), the search yielded 203 results in Scopus and 166 in WoS. Finally, as shown in Figure 2, the database contained 248 articles in total, of which 192 were obtained from Scopus and 56 from WoS.

\subsubsection{Quality assurance and data extraction}

To ensure the quality and relevance of the selected items, the records were individually reviewed to ensure they were original works, and all incidents arising were recorded in a journal. The procedure involved checking whether each of the recovered items met the inclusion criteria to be added to the final database. The database was formed as shown in Figure 2.

\subsubsection{Creation of a classification scheme}

To answer the research questions, a set of categories was established that enabled the analysis of the information of each article in a homogeneous manner. To categorize articles under the Digital Competence Classification, we used the generic competition areas proposed by Ferrari, and used in the Common Framework of the Teaching Digital Competence (Intef), which generically contains the set of competencies of the public, implicitly described in the Framework for Information Literacy for Higher Education and in the Information Literacy Competency Standards for Nursing (Ferrari; Punie; Brečko, 2013; Intef, 2017; ALA, 2013) (Table 4).

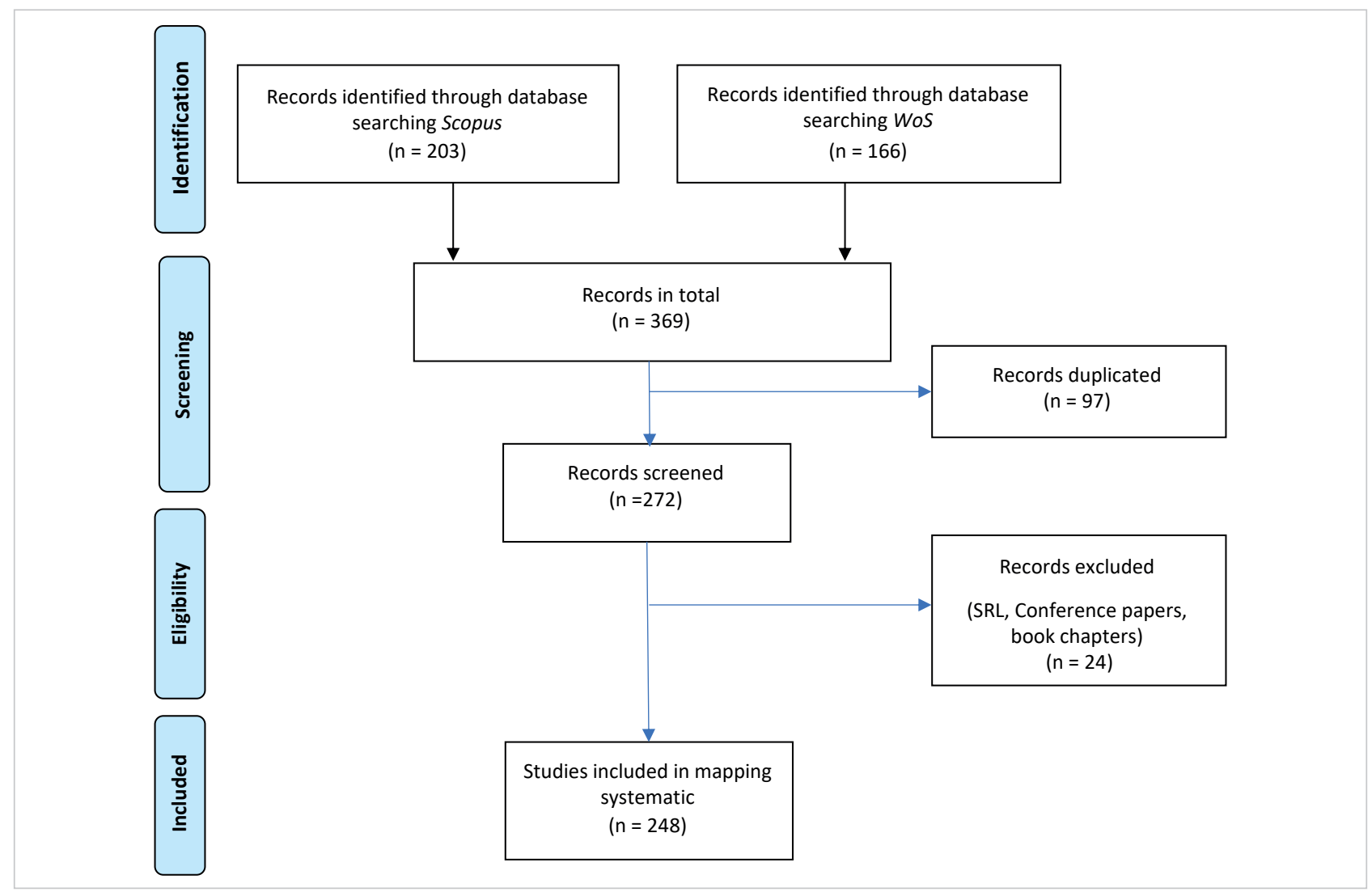

Figure 2. Record selection procedure.

Based on Moher et al., (2009). 
Table 4. Digital competences (DigCom)

\begin{tabular}{|l|l|}
\hline Categories & Description \\
\hline Information literacy & Identify, locate, retrieve, store, organize, and analyze digital information, assessing its purpose and relevance. \\
\hline Communication & $\begin{array}{l}\text { Communicating and collaborating in digital environments, sharing resources through online tools, connecting } \\
\text { and collaborating with others through digital tools, and interacting and participating in communities and } \\
\text { networks; intercultural awareness. }\end{array}$ \\
\hline Security & $\begin{array}{l}\text { Creating and editing new content (texts, images, videos...), integrating and reworking previous knowledge and } \\
\text { content, making artistic productions, multimedia content, computer programming, knowing how to apply } \\
\text { intellectual property rights and licenses for use. }\end{array}$ \\
\hline Problem solving & $\begin{array}{l}\text { Personal protection, data protection, digital identity protection, security use, protecting health, safe and sustai- } \\
\text { nable use. } \\
\text { Solving technical problems, identifying needs and technological responses, innovating and creatively using } \\
\text { technology, identifying digital competence gaps. }\end{array}$ \\
\hline
\end{tabular}

Table 5 shows the classification that was used based on González-Pérez's Emerging topics of educational technology (González-Pérez; Ramírez-Montoya; García-Peñalvo, 2019; Gómez-Zermeño et al., 2019).

Table 5. Educational innovation and use of technology

\begin{tabular}{|l|l|}
\hline Categories & Description \\
\hline Digital pedagogies & $\begin{array}{l}\text { They link pedagogical supports with technologies to adapt to each area of knowledge, such as b-learning, and } \\
\text { environments with multimedia technologies. }\end{array}$ \\
\hline Technological models & $\begin{array}{l}\text { They integrate innovation models with technology, such as smart innovation systems, with design based on } \\
\text { research. }\end{array}$ \\
\hline Adaptive technologies & $\begin{array}{l}\text { They introduce new e-learning systems that adapt to the new needs of society and promote learning and adap- } \\
\text { tive educational systems, such as e-portfolios and Web } 2.0 \text { tools. }\end{array}$ \\
\hline Open technologies & $\begin{array}{l}\text { They enable open access for the dissemination of open knowledge, e.g., open platforms, repositories, open } \\
\text { resources, MOOC, open science }\end{array}$ \\
\hline Smart technologies & $\begin{array}{l}\text { They use smart tools and devices, e.g., big data, data mining and analytics, cloud technologies, cloud compu- } \\
\text { ting in educational contexts, m-learning. }\end{array}$ \\
\hline Disruptive technologies & $\begin{array}{l}\text { They involve new processes and services with leapfrogging technologies, e.g., augmented reality technologies, } \\
\text { sensory stimulation, and abstract images, such as virtual and remote laboratories. }\end{array}$ \\
\hline
\end{tabular}

\subsection{Results}

Through the SMS process, information from research articles was summarized and classified into an Excel database to answer the research questions, obtaining the following results (available in the database via the following link): https://figshare.com/s/73e4cfd8977407320387

\section{RQ1. How many studies are in the Scopus and WoS databases from 2015 to 2019?}

Of the total number of articles, most were identified as empirical studies (81\%). Overall, $13 \%$ were theoretical articles, and $6 \%$ used mixed methods. Table 6 presents a brief summary of the methods used and found in the articles.

\section{RQ2. What are the most cited articles?}

Table 6. Articles in WoS and Scopus and types of research

\begin{tabular}{|l|c|c|c|}
\hline \multicolumn{1}{|c|}{ Research type } & Scopus & WoS & Total \\
\hline Empirical & 162 & 41 & 202 \\
\hline Mixed methods & 9 & 5 & 14 \\
\hline Theoretical & 21 & 10 & 31 \\
\hline Total & 192 & 56 & 248 \\
\hline
\end{tabular}

Approximately half of the items were never cited $(34 \%)$ or were only cited once $(16 \%)$. The other half of the articles (46\%) range from 2 to 10 citations, and 10 articles stand out (4\%), having been cited between 11 and 25 times.

The most cited article investigates information search skills for evidence-based practice for nurses in a hospital (Farokhzadian; Khajouei; Ahmadian, 2015). Further standouts include other digital competence training-oriented articles for health professionals (Wissinger et al., 2018; DeBose; Haugen; Miller, 2017) and librarians (Seeber, 2015), as well as articles addressing the didactic methods used in training (Carroll; Tchangalova; Harrington, 2016; McClurg et al., 2015,) and IL practices for librarians (Ream; Parker-Kelly, 2016; Matlin; Lantzy, 2017; Walters et al., 2015). Table 7 presents the most cited articles in the research. 
Table 7. Most cited articles (cites $\geq 10$ )

\begin{tabular}{|c|c|}
\hline References & Cited \\
\hline $\begin{array}{l}\text { Belanger, Jackie; Zou, Ning; Mills, Jenny-Rushing; Holmes, Claire; Oakleaf, Megan (2015). Project Rails: Lessons learned } \\
\text { about rubric assessment of information literacy skills. Portal. Libraries and the academy, v. 15, n. 4, pp. 623-644. } \\
\text { https://doi.org/10.1353/pla.2015.0050 }\end{array}$ & 12 \\
\hline $\begin{array}{l}\text { Carbery, Alan; Leahy, Sean (2015). “Evidence-based instruction: Assessing student work using rubrics and citation analysis to } \\
\text { inform instructional design". Journal of information literacy, v. 9, n. 1, pp. 74-90. } \\
\text { https://doi.org/10.11645/9.1.1980 }\end{array}$ & 14 \\
\hline $\begin{array}{l}\text { Carroll, Alexander J.; Tchangalova, Nedelina; Harrington, Eileen G. (2016). "Flipping one-shot library instruction: Using } \\
\text { Canvas and pecha kucha for peer teaching". Journal of the medical library association, v. 104, n. 2, pp. 125-130. } \\
\text { https://doi.org/10.3163/1536-5050.104.2.006 }\end{array}$ & 18 \\
\hline $\begin{array}{l}\text { Farokhzadian, Jamileh; Khajouei, Reza; Ahmadian, Leila (2015). "Information seeking and retrieval skills of nurses: Nurses } \\
\text { readiness for evidence based practice in hospitals of a medical university in Iran". International journal of medical informatics, v. } \\
\text { 84, n. 8, pp. 570-577. } \\
\text { https://doi.org/10.1016/j.ijmedinf.2015.03.008 }\end{array}$ & 25 \\
\hline $\begin{array}{l}\text { Greer, Katie; Hess, Amanda-Nichols; Kraemer, Elizabeth W. (2016). "The librarian leading the machine: A reassessment of } \\
\text { library instruction methods". College and research libraries, v. 77, n. 3, pp. 286-301. } \\
\text { https://doi.org/10.5860/crl.77.3.286 }\end{array}$ & 13 \\
\hline $\begin{array}{l}\text { Hess, Amanda-Nichols (2015). "Motivational design in information literacy instruction". Communications in information literacy, } \\
\text { v. 9, n. 1, pp. 44-59. } \\
\text { https://doi.org/10.15760/comminfolit.2015.9.1.175 }\end{array}$ & 12 \\
\hline $\begin{array}{l}\text { Julien, Heidi; Gross, Melissa; Latham, Don (2018). "Survey of information literacy instructional practices in U.S. academic } \\
\text { libraries". College and research libraries, v. 79, n. 2, pp. 179-199. } \\
\text { https://doi.org/10.5860/crl.79.2.179 }\end{array}$ & 11 \\
\hline $\begin{array}{l}\text { McClurg, Caitlin; Powelson, Susan; Lang, Eddy; Aghajafari, Fariba; Edworthy, Steven (2015). "Evaluating effectiveness of } \\
\text { small group information literacy instruction for undergraduate medical education students using a pre- and post-survey study } \\
\text { design". Health information and libraries journal, v. 32, n. 2, pp. 120-130. } \\
\text { https://doi.org/10.1111/hir.12098 }\end{array}$ & 17 \\
\hline $\begin{array}{l}\text { Seeber, Kevin-Patrick (2015). "Teaching 'format as a process' in an era of web-scale discovery". Reference services review, v. } 43, \mathrm{n} . \\
\text { 1, pp. 19-30. } \\
\text { https://doi.org/10.1108/RSR-07-2014-0023 }\end{array}$ & 15 \\
\hline $\begin{array}{l}\text { Zhao, Jenifer-Congyan; Mawhinney, Tara (2015). "Comparison of native Chinese-speaking and native English-speaking engi- } \\
\text { neering students' information literacy challenges". Journal of academic librarianship, v. 41, n. 6, pp. 712-724. } \\
\text { https://doi.org/10.1016/j.acalib.2015.09.010 }\end{array}$ & 14 \\
\hline
\end{tabular}

\section{RQ3. What is the geographical distribution of the authors?}

The first author was used to identify the geographical origin of the studies. A total of $90 \%$ of research publications were produced mainly in English-speaking countries in the following order: the USA, the UK, South Africa, Canada, and Australia. This information might be useful for researchers who wish to further contextualize these studies. Figure 3 shows the geographical places where the research has been carried out in more detail.

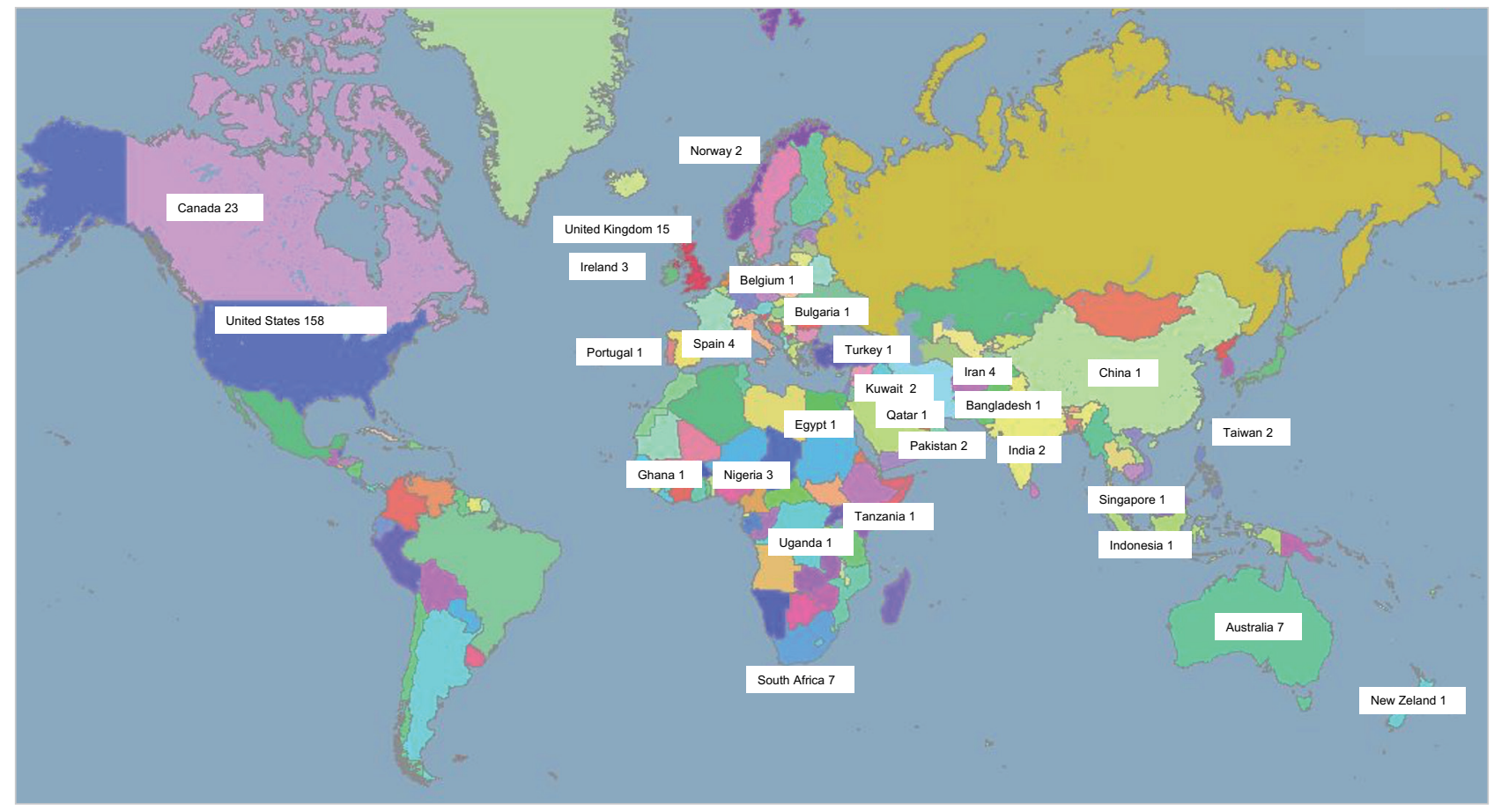

Figure 3. Geographical distribution of published papers 


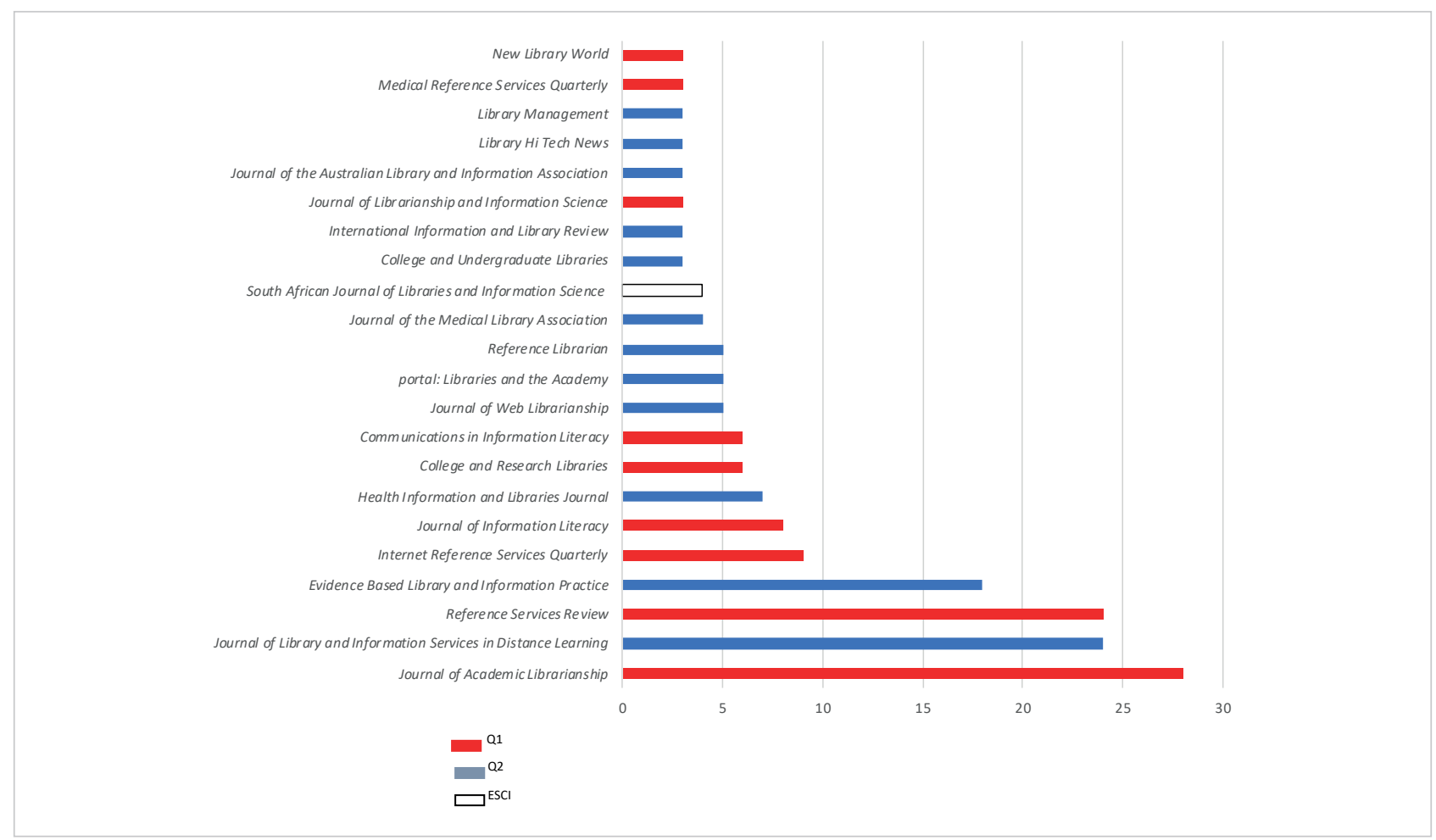

Figure 4. Papers published in the journals

\section{RQ4. What journals have the most publications in this line of research?}

The journals analyzed are classified in the subjects of Library Science, Information Science, Education, and Electronic Library. Overall, 35\% of the titles were in the Q1 ranking in these subjects within the Journal Citation Reports (JCR) or the SCImago Journal Rank (SJR) Q1. Further, 48\% were in Q2, 6\% were in Q3, and 4\% were in Q4, the other $8 \%$ were in ESCI.

Four journals account for 39\% of the papers and have a Q1 or Q2 ranking. By default, the value of the quartile of the journal in SJR was chosen, only in the case that the journal was not indexed in Scopus the value of JCR or ESCI was selected. The ranking version was from 2018, which was available when the data were analyzed. Figure 4 shows the papers published in the journals.

\section{RQ5. In what contexts are the studies being conducted?}

More than half of the articles (68\%) dealt with research conducted in the academic context of higher education involving health science students (doctors, nurses, therapists, etc.), and most dealt with the dimension of information or IL skills, followed distantly by communication skills. Few works were developed in the context of health institutions (hospitals, primary care centers, etc.). The competencies researched were overwhelmingly in the information dimension in all educational contexts, followed (at a distance) by communication, content creation, security, and problem solving. Figure 5 shows the published articles on digital literacy and research.

RQ6. What are the categories of digital competencies that have been studied?

According to Ferrari's classification of the five dimensions of the European Framework of Digital Competence, most of the articles dealt with dimension 1 , Information, specifically focused on training imparted from the library to acquire the cross-sectional competence that is also included in the $A C R L$ instructional standards. Publications classified in di-

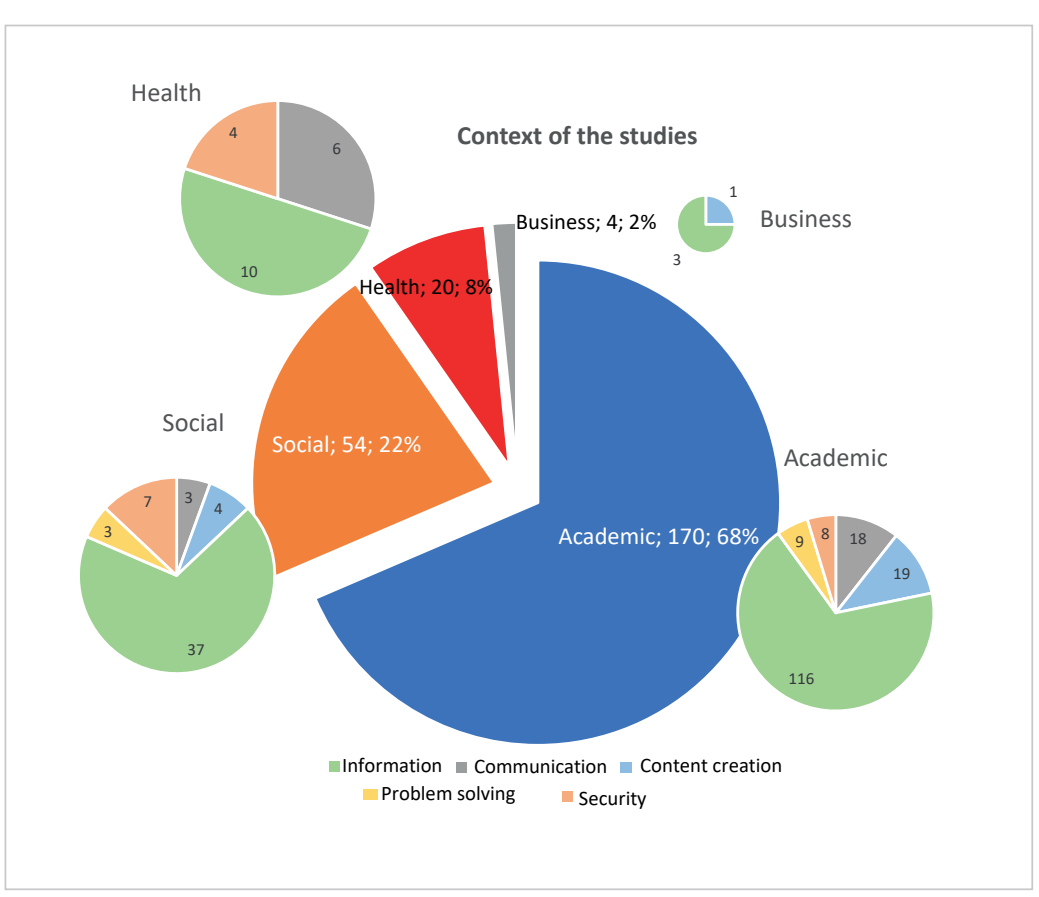

Figure 5. Published articles on digital literacy and research 


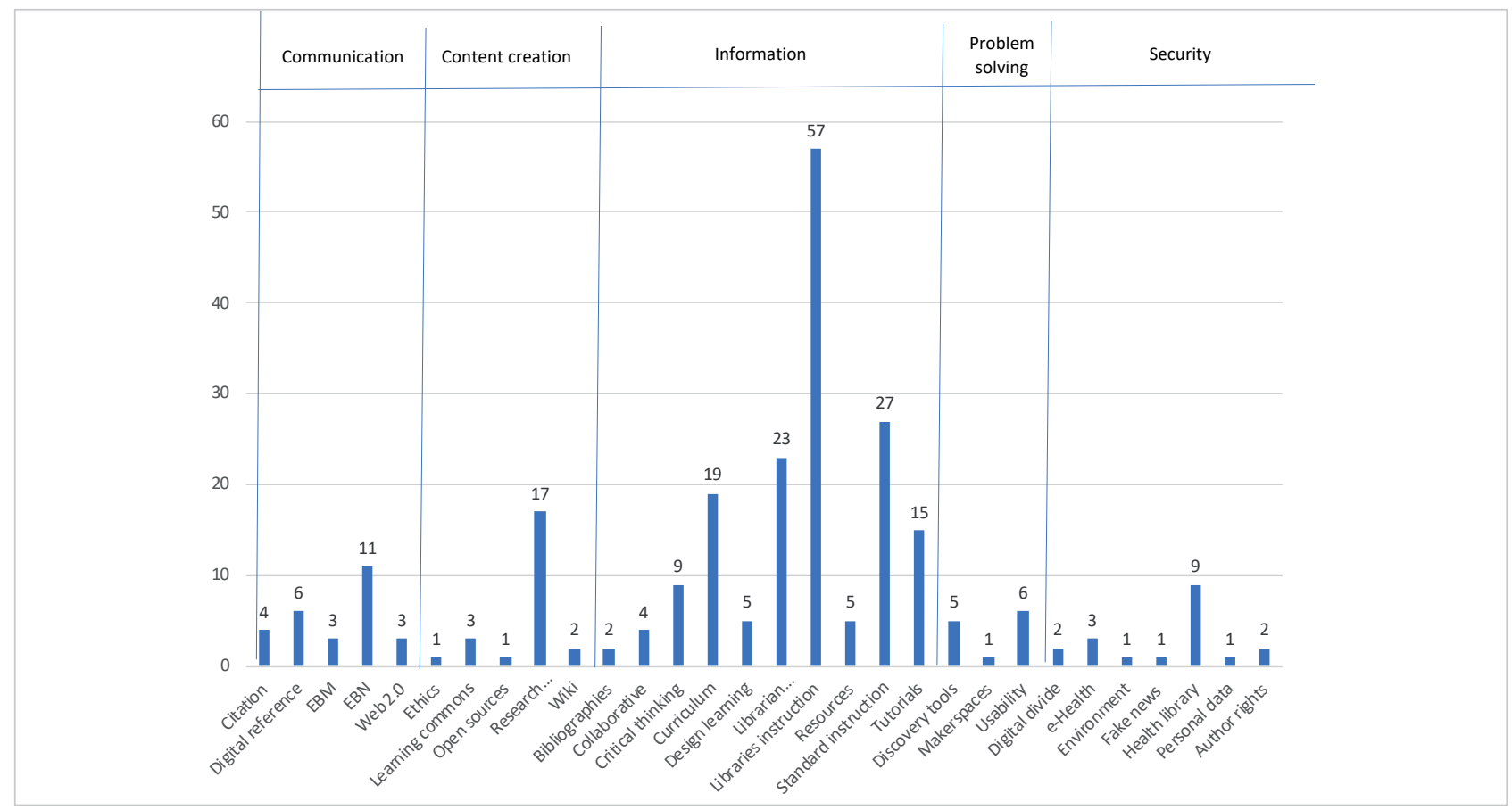

Figure 6. Category of digital competence

mension 2, Communication, dealt with nursing and evidence-based medicine. In dimension 3, Content creation, articles relating to research competition were classified. Dimension 4, Problem solving, and dimension 5, Security, were the least represented. In the Security dimension, there were nine papers on health literacy and e-health. Figure 6 shows the different categories of digital competence found.

Based on an analysis of the keywords of the articles recovered from the Scopus database, the predominant term was "Information Literacy" and its relationship with other terms. Figure 7 shows the map of relations of the keywords found in Scopus.

\section{RQ7. What are the digital technologies that have resulted in emerging issues in digital education?}

The educational innovations used in training activities are digital education (48\%), adaptative technologies (26\%), open technologies (20\%), technological models (4\%), and smart technologies (1\%) (Figure 8).

The connection between the educational technology dimension and digital competence can be seen from the intersection between both dimensions. If we analyze the set of articles, we observe that most of them investigate training in information competence using educational digital technology (82), adaptive technologies (45), and open technologies (30). Figure 9 shows the educational technologies used in the formation of the competencies.

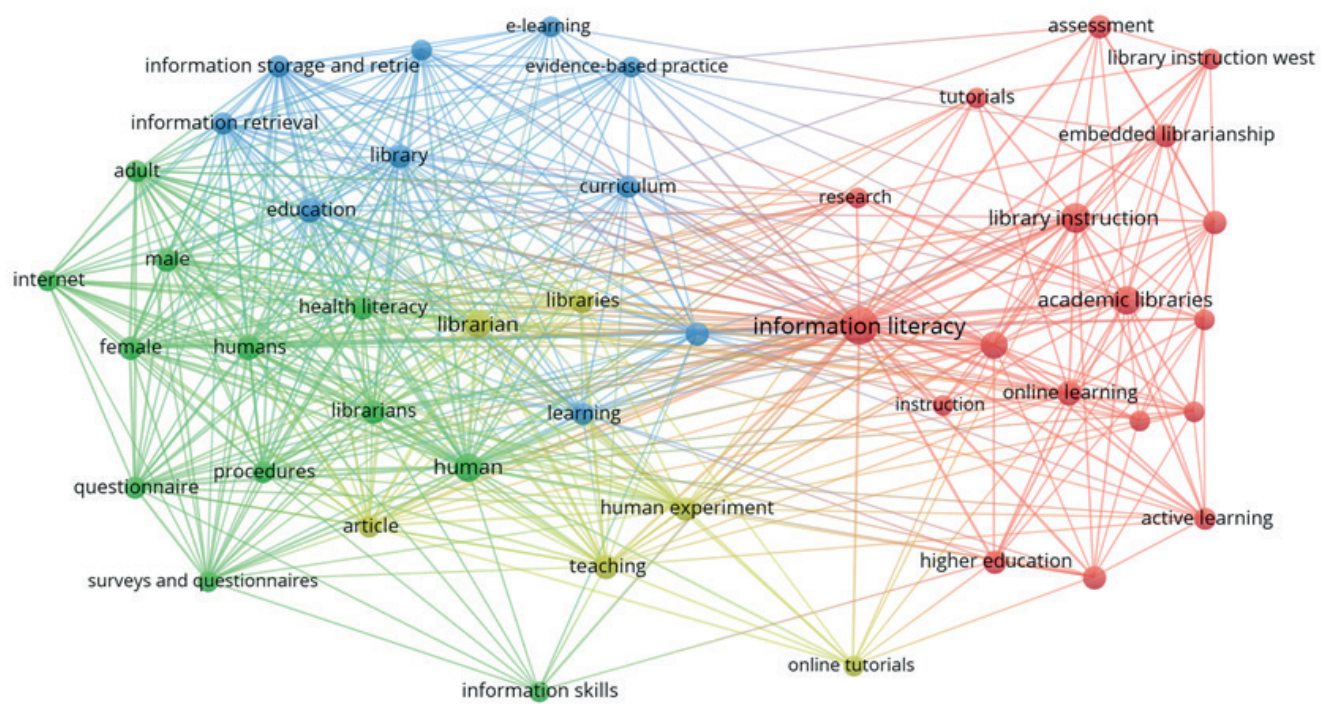

Figure 7. Map of relations of the keywords found in Scopus. 


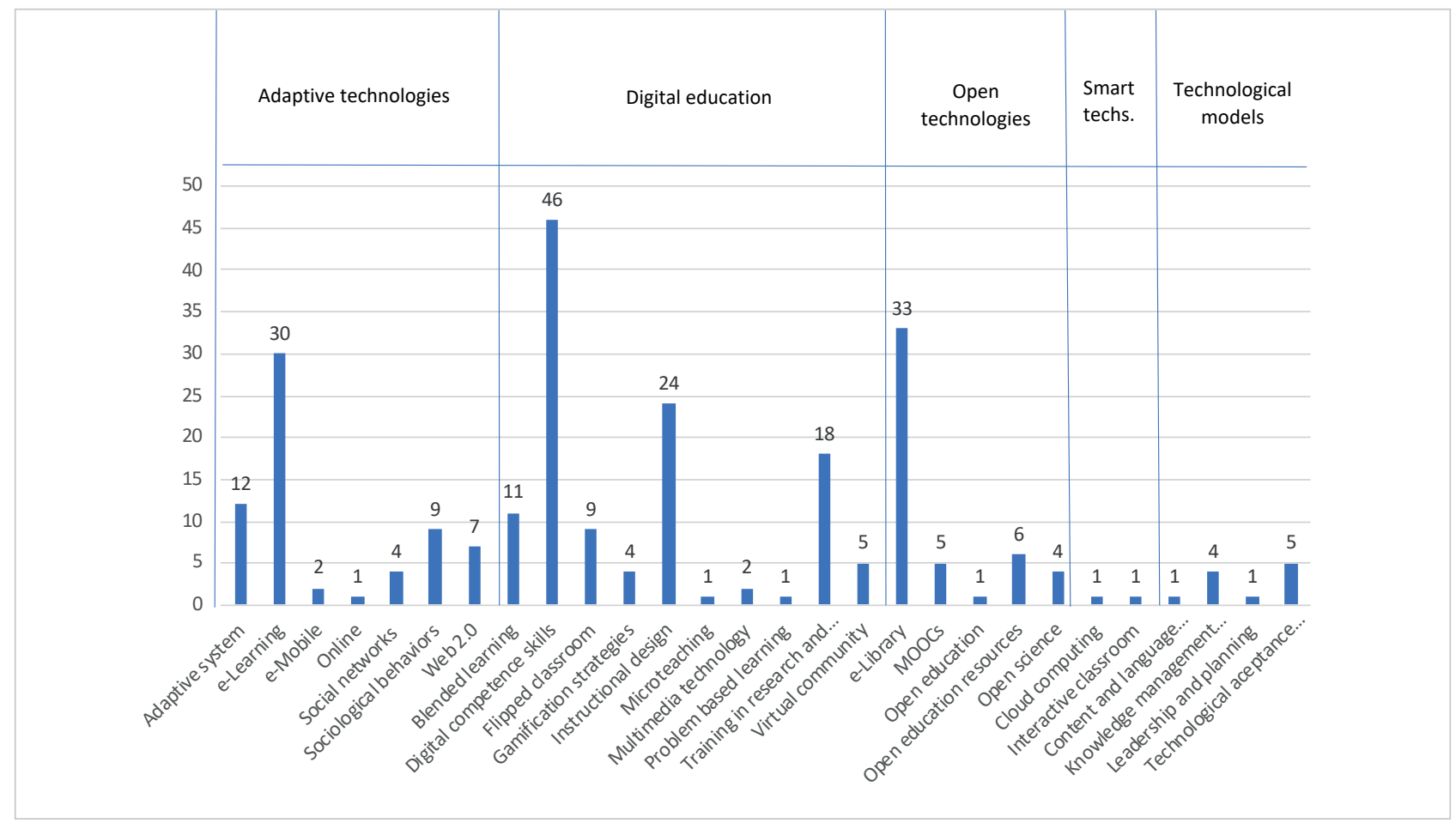

Figure 8. Use of educational technologies in digital competencies

The chronological evolution during the five years analyzed shows an upward trend in the first two years of the study and continues with a downward trend during the last three years. The year 2016 has the greatest number of documents, and the dimension of digital information competence and the emerging educational technology used is digital pedagogy.

\section{Discussion}

The documents found on digital competence learning aimed at health professionals were developed mainly in the academic context. Specifically, they involved the university context and, to a much lesser extent, the workplace, where professionals develop their activities. The Ferrari Digital Competence framework recommends that training should be provided at all educational, work, and social levels (Ferrari; Punie; Brečko, 2013). Librarians and information researchers have argued for the importance of competence and

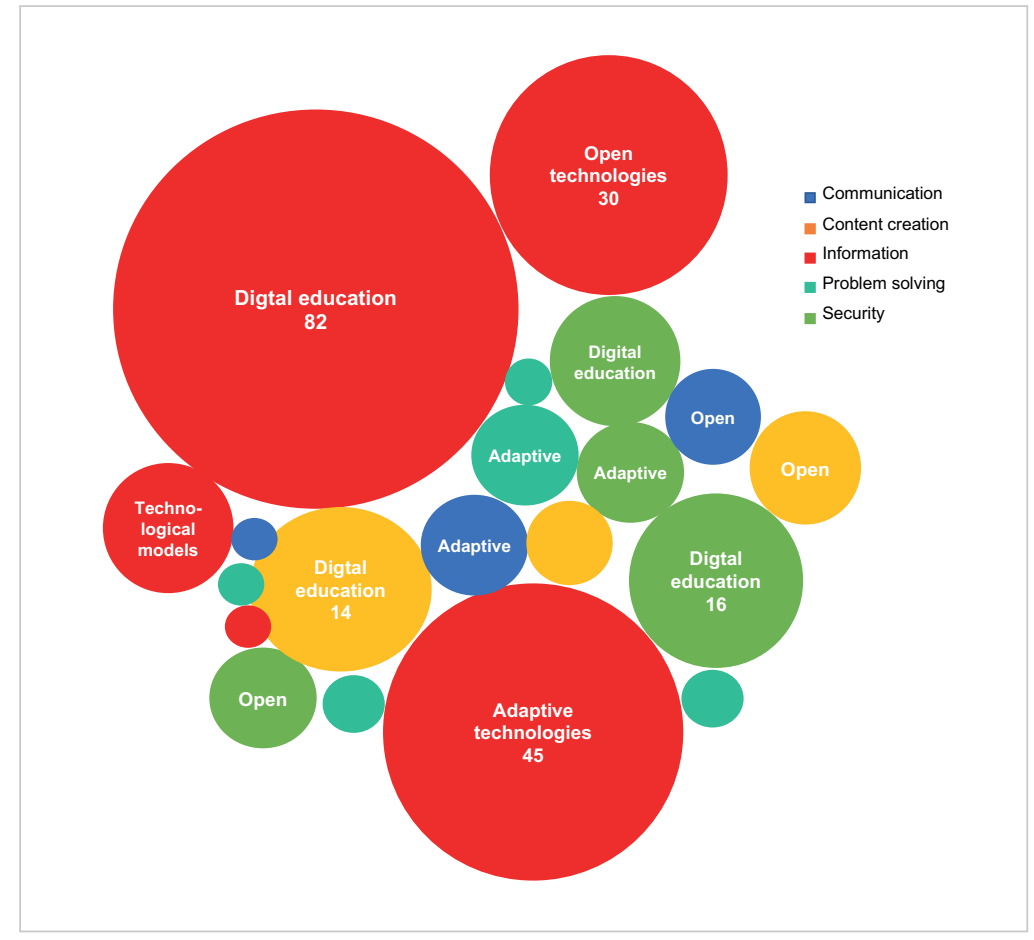

Figure 9. Educational technologies used in the formation of the digital competencies selecting a frame of reference that articulates the entire training process (Pinto; Cordón-García; Gómez-Díaz, 2010). Despite these recommendations, this type of training is lacking in lifelong learning in a professional health context.

There is growing interest among researchers in the field of pedagogy, librarians, and documentarians to adopt a conceptual model that serves as a framework for designing training programs with a high quality. The analyzed articles mention the $A C R L$ framework. Wissinger assesses the positive results of training in a library-led teaching program used by the ACRL framework (Wissinger et al., 2018). Twenty articles use the ACRL framework for IL for higher education as a reference for the instruction and design of training activities. DeBose et al. present an IL program aimed at students and life science teachers with an up-to-date view of the IL concept that encompasses the ability to assess the impact of information, appropriate data management practices, copyright, and ethical use of information and highlights the importance of integrating changes in scientific communication into curriculum design (DeBose; Haugen; Miller, 2017). Only one article made an explicit reference to the European DigCom framework for digital skills training for health professionals (Fer- 


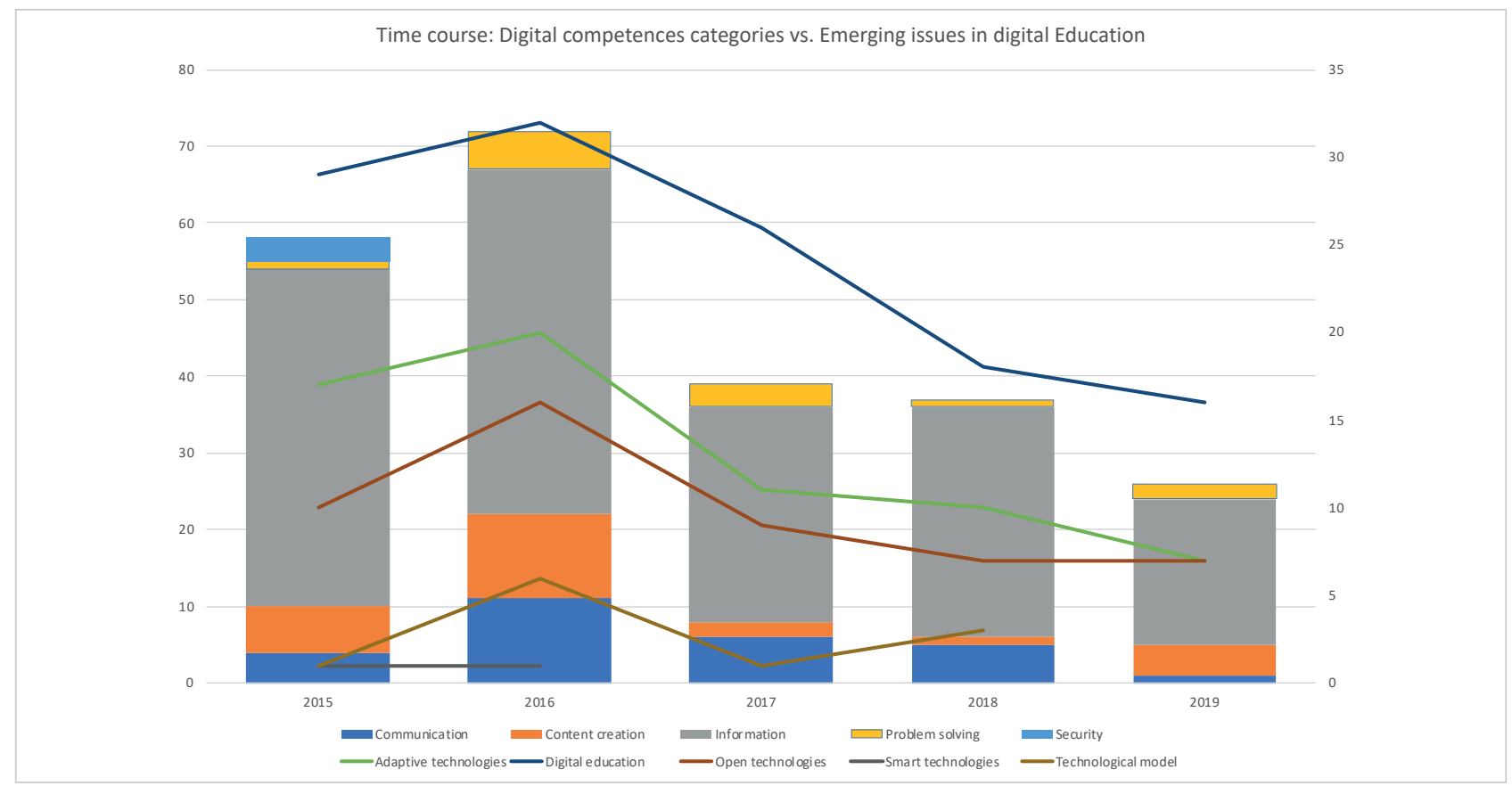

Figure 10. Time course. Digital competence categories versus education innovation and use of technology.

nández-Luque, 2019). The majority of the articles belong to the Anglo-American sphere, and perhaps this is why they have chosen the competence framework of the ACRL (Figure 3). Training is mostly focused in the information dimension (Figure 6), with the other dimensions receiving less attention. Under the constructivist paradigm, both Laanpere (2019) and Ferrari, Punie \& Brečko (2013) propose a theoretical framework of reference that is taken into account throughout the training process. Most of the documents analyzed do not include the associated frame of reference and treat training as a set of one-off activities for training available resources from the library rather than as activities integrated into the curriculum to achieve cross-sectional digital competence.

The analyzed publications included active learning methodologies with innovative educational technologies, as libraries use technology tools to access information (devices, search engine management, metadata, etc.). Thus, it is essential to teach using technological tools that incorporate innovative educational technologies. Carroll et al. use the inverted classroom technique to facilitate peer learning and improve the ability of health science students to find, evaluate, and use evidence (Carroll; Tchangalova; Harrington, 2016). Ajuwon et al. analyze motivational factors among physicians residing in health institutions and suggest involving other disciplines to design content through technological systems for training (Ajuwon et al., 2017). Abrizah, Inuwa and Afiqah-Izzati (2016) highlight the importance of librarians in digital literacy training, online training, and connecting with different health departments. Educational innovation technologies focus mostly on digital education using open e-library technologies, adaptive technologies that employ e-learning, and blended learning in increasingly less face-to-face training (Figure 8). As Ramírez-Montoya points out, including pedagogical technologies in innovative learning environments helps to ensure the achievement of learning goals (2020). In these digital learning environments, the teacher/facilitator needs to be aware of the advantages of consciously using innovative pedagogical technologies in active learning environments to achieve the best results.

Health librarians provide training for program management, consultation tools, loan service management, web use, etc. Most of the time, this teaching program is included in the official curriculum design (Maggio; Durieux; Tannery, 2015). The documents revealed a significant number of activities that librarians perform based on their formative role (Gómez-Hernández, 2009). The training contents focus on the Information dimension, and according to the keywords of the articles, the most repeated term is "Information Literacy" (Figure 7). Fernández-Ramos (2016), Matlin and Lantzy 2(017), Ream and Parker-Kelly (2016), and Walters et al. (2015) examine the role of the librarian in creating tutorials in various formats, as well as the role of these tutorials in training based on active learning. McClellan includes the role of the teacher-librarian to integrate critical thinking into users' training plans (McClellan, 2016). The World Health Organization has sued governments and health institutions to require them to take the necessary steps to ensure that health professionals have the necessary skills to interact in a technology-based globalized world (WHO, 2019). Library reference frameworks recommend active learning methods to achieve this goal (Berg, 2020). Librarians are already interacting in innovative and disruptive learning environments to gain competence in different technological environments (Pinto et al., 2019). The results indicate that the design of the programs should be based on active and innovative learning methods using active learning processes in an innovative environment so that the health professional can be trained to act in the digital medium of e-health, which is already a part of everyday professional practice. Moreover, librarians need specialized training that includes methods of instructional design for digital environments and active learning that encourages the innovation and development of digital competence throughout life. 
Evidence points to the need to strengthen the methodological foundations of research in digital competencies as basic pillars for the critical and strategic use of health information for clinical, teaching, and research practice. This involves the use of educational technology in the workplace linked to the use of digital information. The librarian must develop competence to serve in a training role. The reviewed works examined educational technologies and training platforms in the context of the global web [36-38]. The most commonly used technologies were digital, adaptive, and open pedagogies (Figure 8). The results show that educational technology is important for achieving digital competence, and the library is contributing to achieving this goal (Ramírez-Montoya; Lugo-Ocando, 2020; Alonso-Arévalo; Vázquez-Vázquez, 2018).

The current circumstances generated by Covid-19 have led many health professionals to work online and carry out their work and research activities virtually. Thus, these professionals have recognized the cross-cutting nature of digital competence and advocate for the incorporation of active learning methodologies to achieve effective levels of training and thus be able to apply them in professional practice (Domínguez-Aroca; Grupo \#AyudaBiblioteca, 2020).

Digital skills have been strengthened due to the emergence of new paradigms, such as open access, alternative metrics, and social networks, demonstrating the need to strengthen this competence to meet people's academic, professional, and personal needs at different stages.

\subsection{Limitations and future study}

The study presents an overview of the interest in the topic of e-skills training targeting health professionals and points to the need to strengthen the frame of reference, that is, a Framework for Digital Competence Training. This requires a commitment to continuing training as a fundamental element of lifelong learning.

Among the challenges is the need to carry out scientific research on the possibilities arising from the application of the open innovation paradigm in the field of digital competence training. For example, research is needed regarding the development of sustainable training environments, as health professionals must interact in a changing technological environment and require training in the use and management of an ever-changing information ecosystem.

Another challenge is how librarians can participate in the implementation of these competencies in solving real problems. To this end, it would be advisable to involve educational policy developers linked to academic authorities, the company, and the government so as to include these cross-sectional competencies in the curricula of health professionals at all levels, as well as in the training of librarians-teachers.

Looking ahead, formative experiences must be scored and evaluated, determining their success or failure, disseminating the results extensively, and sharing the recommendations with the educational community, in such a way that learning methods could be replicated or improved in the same or other academic or working contexts.

We would like to state that the articles discussed here were found in the Scopus and WoS databases, and so there is an opportunity to expand the analysis with the inclusion of other databases. This SMS serves as the basis for future research aiming to explore the contributions of digital skills training aimed at health professionals in the workplace in greater detail. Moreover, it is an invitation to further consolidate training in digital skills, not only for health professionals but for all fields where the use of information is crucial for educational, social, and cultural development.

\section{References}

Abrizah, Abdulah; Inuwa, Samaila; Afiqah-Izzati, Nur (2016). "Systematic literature review informing LIS professionals on embedding librarianship roles". Journal of academic librarianship, v. 42, n. 6, pp. 636-643.

https://doi.org/10.1016/j.acalib.2016.08.010

Ajuwon, Grace A.; Kamau, Nancy; Kinyengyere, Alison; Muziringa, Misimba (2017). "Consumer health information literacy promotion program in public and community libraries in Africa: Experience from Kenya, Nigeria, Uganda, and Zimbabwe". Journal of consumer health on the internet, v. 21, n. 4, pp. 350-368.

https://doi.org/10.1080/15398285.2017.1376180

Alonso-Arévalo, Julio; Vázquez-Vázquez, Marta (2018). "La contribución de la biblioteca universitaria al logro de los planes y proyectos de la institución”. Cuadernos de documentación multimedia, v. 29, pp. 43-53.

https://doi.org/10.5209/CDMU.60033

American Library Association (2013). Information literacy competency standards for nursing". Association of College \& Research Libraries (ACRL).

http://www.ala.org/acrl/standards/nursing

Belanger, Jackie; Zou, Ning; Mills, Jenny-Rushing; Holmes, Claire; Oakleaf, Megan (2015). Project Rails: Lessons learned about rubric assessment of information literacy skills. Portal. Libraries and the academy, v. 15, n. 4, pp. 623-644.

https://doi.org/10.1353/pla.2015.0050

Berg, Cara (2020). "Updating learning outcomes and engaging library faculty with the ACRL framework". The journal of academic librarianship, v. 46, n. 2, 102040.

https://doi.org/10.1016/j.acalib.2019.05.008 
Campal-García, Felicidad (2019). “Hacia una ciudadanía del s. XXI: formada, informada, responsable, dinámica, comprometida y libre, también desde las bibliotecas". Desiderata, n. 11, pp. 34-41.

https://dialnet.unirioja.es/servlet/articulo?codigo=6885099

Carbery, Alan; Leahy, Sean (2015). "Evidence-based instruction: Assessing student work using rubrics and citation analysis to inform instructional design". Journal of information literacy, v. 9, n. 1, pp. 74-90.

https://doi.org/10.11645/9.1.1980

Carroll, Alexander J.; Tchangalova, Nedelina; Harrington, Eileen G. (2016). “Flipping one-shot library instruction: Using Canvas and pecha kucha for peer teaching". Journal of the Medical Library Association, v. 104, n. 2, pp. 125-130.

https://doi.org/10.3163/1536-5050.104.2.006

Coonan, Emma; Geekie, Jackeline; Goldstein, Stéphane; Jeskins, Lisa; Jones, Rosie; Macrae-Gibson, Roswena; Secker, Jane; Walton, Geoff (2018). Cilip. Definition of information literacy. Information Literacy Group.

https://infolit.org.uk/ILdefinitionCILIP2018.pdf

Cooper, I. Diane (2016). "What is a 'mapping study?'”. Journal of the Medical Library Association, v. 104, n. 1, pp. $76-78$. https://doi.org/10.3163/1536-5050.104.1.013

DeBose, Kyrille-Goldbeck; Haugen, Inga; Miller, Rebecca K. (2017). “Information literacy instruction programs: Supporting the College of Agriculture and Life Sciences community at Virginia Tech". Library trends, v. 65, n. 3, pp. 316-338.

https://doi.org/10.1353/lib.2017.0004

Domínguez-Aroca, María-Isabel; Grupo \#AyudaBiblioteca (2020). "Cooperación de profesionales de las bibliotecas de Ciencias de la Salud como respuesta a la pandemia de la Covid-19". Profesional de la información, v. 29 , n. 4, e290430. https://doi.org/10.3145/epi.2020.jul.30

Farokhzadian, Jamileh; Khajouei, Reza; Ahmadian, Leila (2015). "Information seeking and retrieval skills of nurses: Nurses readiness for evidence based practice in hospitals of a medical university in Iran". International journal of medical informatics, v. 84, n. 8, pp. 570-577.

https://doi.org/10.1016/j.ijmedinf.2015.03.008

Fernández-Luque, Antonia-María (2019). “La formación en competencias digitales de los profesionales de la salud en el lugar de trabajo". Revista cubana de información en ciencias de la salud, v. 30, n. 2.

http://scielo.sld.cu/pdf/ics/v30n2/2307-2113-ics-30-02-e1322.pdf

Fernández-Ramos, Andrés (2016). "Factores de éxito en tutoriales en línea de competencias informacionales. Revisión sistemática". Revista española de documentación científica, v. 39, n. 2.

https://doi.org/10.3989/redc.2016.2.1291

Ferrari, Anusca; Punie, Yves; Brečko, Barbara N. (2013). Digcomp: a framework for developing and understanding digital competence in Europe. Institute for Prospective Technological Studies. ISBN: 9789279314650

https://doi.org/10.2788/52966

García-González, Abel; Ramírez-Montoya, María-Soledad (2019). “Systematic mapping of scientific production on open innovation (2015-2018): Opportunities for sustainable training environments". Sustainability, v. 11, n. 6, 1781.

https://doi.org/10.3390/su11061781

Gómez-Hernández, José-Antonio (2009). “Aprender a enseñar competencias informacionales a los usuarios: avances en la formación profesional en España". Anuario ThinkEPI, v. 3, pp. 106-113.

https://recyt.fecyt.es/index.php/ThinkEPI/article/view/32003

Gómez-Zermeño, Marcela G.; Alemán-de-la-Garza, Lorena; Portuguez-Castro, May I.; Medina-Labrador, Manuel I. (2019). "Innovación educativa en estudios sobre el desarrollo y uso de la tecnología: Una revisión sistemática de literatura”. En: Ramírez-Montoya, María-Soledad; Valenzuela-González, Jaime-Ricardo. Innovación educativa: tendencias globales de investigación e implicaciones prácticas. Barcelona: Octaedro, pp. 197-218. ISBN: 9788417667788 https://repositorio.grial.eu/handle/grial/1819

González-Fernández-Villavicencio, Nieves (2015). “DigComp o la necesaria adecuación al marco común de referencia en competencias digitales". Anuario ThinkEPI, v. 9, pp. 30-35.

https://doi.org/10.3145/thinkepi.2015.04

González-Pérez, Laura-Icela; Ramírez-Montoya, María-Soledad; García-Peñalvo, Francisco J. (2019). “Innovación educativa en estudios sobre el desarrollo y uso de tecnología: Un mapeo sistemático". En: Ramírez-Montoya, María-Soledad; Valenzuela-González, Jaime-Ricardo. Innovación educativa: tendencias globales de investigación e implicaciones prácticas. Barcelona: Octaedro, pp. 171-192. ISBN: 9788417667788

https://repositorio.grial.eu/handle/grial/1816 
Greer, Katie; Hess, Amanda-Nichols; Kraemer, Elizabeth W. (2016). “The librarian leading the machine: A reassessment of library instruction methods". College and research libraries, v. 77, n. 3, pp. 286-301.

https://doi.org/10.5860/crl.77.3.286

Hernández-Carranza, Erika-Elvira; Romero-Corella, Sandra-Irene; Ramírez-Montoya, María-Soledad (2015). "Evaluación de competencias digitales didácticas en cursos masivos abiertos: Contribución al movimiento latinoamericano". Comunicar, v. 22, n. 44, pp. 81-90.

https://doi.org/10.3916/C44-2015-09

Hess, Amanda-Nichols (2015). "Motivational design in information literacy instruction". Communications in information literacy, v. 9, n. 1, pp. 44-59.

https://doi.org/10.15760/comminfolit.2015.9.1.175

Iannuzzi, Patricia (2000). "Information literacy competency standards for higher education". Community \& junior college libraries, v. 9, n. 4, pp. 63-67.

https://doi.org/10.1300/J107v09n04_09

Intef (2017). Common digital competence framework for teachers. Instituto Nacional de Tecnologías Educativas y de Formación del Profesorado.

http://aprende.intef.es/sites/default/files/2018-05/2017_1024-Common-Digital-Competence-Framework-For-Teachers.pdf

Julien, Heidi; Gross, Melissa; Latham, Don (2018). "Survey of information literacy instructional practices in U.S. academic libraries". College and research libraries, v. 79, n. 2, pp. 179-199.

https://doi.org/10.5860/crl.79.2.179

Kitchenham, Barbara; Pretorius, Rialette; Budgen, David; Brereton, O. Pearl; Turner, Mark; Niazi, Mahmood; Linkman, Stephen (2010). "Systematic literature reviews in software engineering - A tertiary study". Information and software technology, v. 52, n. 8, pp. 792-805.

https://doi.org/10.1016/j.infsof.2010.03.006

Kroll, Josiane; Richardson, Ita; Prikladnicki, Rafael; Audy, Jorge L. N. (2018). "Empirical evidence in follow the sun software development: A systematic mapping study". Information and software technology, v. 93, pp. 30-44.

https://doi.org/10.1016/j.infsof.2017.08.011

Laanpere, Mart (2019). Recommendations on assessment tools for monitoring digital literacy within Unesco's digital literacy global gramework. Unesco Biblioteca Digital.

https://unesdoc.unesco.org/ark:/48223/pf0000366740

Ma, Jinxuan; Stahl, Lynne; Knotts, Erica (2018). "Emerging roles of health information professionals for library and information science curriculum development: a scoping review". Journal of the Medical Library Association, v. 106, n. 4. https://doi.org/10.5195/jmla.2018.354

Maggio, Lauren A.; Durieux, Nancy; Tannery, Nancy H. (2015). "Librarians in evidence-based medicine curricula: A qualitative study of librarian roles, training, and desires for future development". Medical reference services quarterly, v. 34, n. 4, pp. $428-440$. https://doi.org/10.1080/02763869.2015.1082375

Matlin, Talitha R.; Lantzy, Trizia (2017). “Maintaining quality while expanding our reach: Using online information literacy tutorials in the sciences and health sciences". Evidence based library and information practice, v. 12, n. 3, pp. 95-113. https://doi.org/10.18438/B8ZD3Q

McClellan, Samantha (2016). "Teaching critical thinking skills through commonly used resources in course-embedded online modules". College and undergraduate libraries, v. 23, n. 3, pp. 295-314.

https://doi.org/10.1080/10691316.2014.987416

McClurg, Caitlin; Powelson, Susan; Lang, Eddy; Aghajafari, Fariba; Edworthy, Steven (2015). “Evaluating effectiveness of small group information literacy instruction for undergraduate medical education students using a pre- and post-survey study design". Health information and libraries journal, v. 32, n. 2, pp. 120-130.

https://doi.org/10.1111/hir.12098

McGowan, Bethant-Sheriese (2019). "Reimagining information literacy instruction in an evidence-based practice nursing course for undergraduate students". Journal of the Medical Library Association, v. 107, n. 4, pp. 572-578. https://doi.org/10.5195/jmla.2019.663

Muellenbach, Joanne M.; Houk, Kathryn M.; Thimons, Dana E.; Rodriguez, Bredny (2018). "Integrating information literacy and evidence-based medicine content within a new school of medicine curriculum: Process and outcome". Medical reference services quarterly, v. 37, n. 2, pp. 198-206.

https://doi.org/10.1080/02763869.2018.1439225

OECD (2019). OECD Skills Outlook 2019. OECD.

https://doi.org/10.1787/df80bc12-en 
Pinto, María; Cordón-García, José-Antonio; Gómez-Díaz, Raquel (2010). “Thirty years of information literacy (19772007): A terminological, conceptual and statistical analysis". Journal of librarianship and information science, v. 42, n. 1, pp. 3-19.

https://doi.org/10.1177/0961000609345091

Pinto, María; Escalona-Fernández, María-Isabel; Pulgarín, Antonio (2013). "Information literacy in social sciences and health sciences: a bibliometric study (1974-2011)". Scientometrics, v. 95, n. 3, pp. 1071-1094.

https://doi.org/10.1007/s11192-012-0899-y

Pinto, María; Fernández-Pascual, Rosaura; Caballero-Mariscal, David; Sales, Dora; Guerrero, David; Uribe, Alejandro (2019). "Scientific production on mobile information literacy in higher education: a bibliometric analysis (2006-2017)". Scientometrics, v. 120, n. 1, pp. 57-85. https://doi.org/10.1007/s11192-019-03115-x

Ramírez-Montoya, María-Soledad; Lugo-Ocando, Jairo (2020). "Revisión sistemática de métodos mixtos en el marco de la innovación educativa". Comunicar, v. 28, n. 65.

https://doi.org/10.3916/C65-2020-01

Ream, Tim; Parker-Kelly, Darlene (2016). "Expanding library services and instruction through LibGuides". Medical reference services quarterly, v. 35, n. 3, pp. 342-349.

https://doi.org/10.1080/02763869.2016.1189790

Sales, Dora (2020). “Definición de alfabetización informacional de Cilip, 2018". Anales de documentación, v. 23, n. 1. https://doi.org/10.6018/analesdoc.373811

Sample, Angela (2020). "Historical development of definitions of information literacy: A literature review of selected resources". The journal of academic librarianship, v. 46, n. 2, p. 102116.

https://doi.org/10.1016/j.acalib.2020.102116

Seeber, Kevin-Patrick (2015). "Teaching 'format as a process' in an era of web-scale discovery". Reference services review, v. 43, n. 1, pp. 19-30.

https://doi.org/10.1108/RSR-07-2014-0023

Steen, Laila; Mao, Xianqing (2016). "Digital skills for health professionals". In: Re-thinking European healthcare. European Health Parliament, pp. 37-47.

https://www.researchgate.net/publication/311271370_Digital_skills_for_health_professionals

Strelan, Peter; Osborn, Amanda; Palmer, Edward (2020). "The flipped classroom: A meta-analysis of effects on student performance across disciplines and education levels". Educational research review, v. 30 .

https://doi.org/10.1016/j.edurev.2020.100314

Valenzuela-González, Jaime-Ricardo (2016). "Competencias transversales para una sociedad basada en conocimiento". En: Valenzuela-González, Jaime-Ricardo (coord.). Competencias transversales para una sociedad basada en conocimiento. Cengage Learning, p. 40. ISBN: 9786075228587

Walters, Kirsteen; Bolich, Cecilia; Duffy, Daniel; Quinn, Ciaran; Walsh, Kathryn; Connolly, Sarah (2015). “Developing online tutorials to improve information literacy skills for second-year nursing students of University College Dublin". New review of academic librarianship, v. 21, n. 1, pp. 7-29.

https://doi.org/10.1080/13614533.2014.891241

Wissinger, Christina L.; Raish, Victoria; Miller, Rebecca K.; Borrelli, Steve (2018). "Expert teams in the academic library: going beyond subject expertise to create scaffolded instruction". Journal of library administration, v. 58, n. 4, pp. 313-333. https://doi.org/10.1080/01930826.2018.1448648

WHO (2016). From innovation to implementation: eHealth in the WHO European Region, World Health Organization. Regional Office for Europe. ISBN: 9789289051378

https://apps.who.int/iris/handle/10665/326317

WHO (2019). Guideline recommendations on digital interventions for health system strengthening. Geneva. ISBN: 978 9241550505

https://www.ncbi.nlm.nih.gov/books/NBK541902/

Zhao, Jenifer-Congyan; Mawhinney, Tara (2015). "Comparison of native Chinese-speaking and native English-speaking engineering students' information literacy challenges". Journal of academic librarianship, v. 41, n. 6, pp. $712-724$. https://doi.org/10.1016/j.acalib.2015.09.010

Ziegenfuss, Donna-Harp; LeMire, Sarah (2019). "Information literacy and instruction: Backward design: A must-have library instructional design strategy for your pedagogical and teaching toolbox". Reference \& user services quarterly, $\mathrm{v}$. 59, n. 2, pp. 107-112.

https://doi.org/10.5860/rusq.59.2.7275 